\title{
Methionine Restriction and Cancer Biology
}

\author{
Desiree Wanders, Katherine Hobson and Xiangming Ji * \\ Department of Nutrition, Byrdine F. Lewis College of Nursing and Health Professions, Georgia State University, \\ Atlanta, GA 30302, USA; dwanders@gsu.edu (D.W); khobson3@student.gsu.edu (K.H) \\ * Correspondence: xji4@gsu.edu; Tel.: 404-413-1242; Fax: 404-413-1228
}

Received: 7 February 2020; Accepted: 1 March 2020; Published: 3 March 2020

\begin{abstract}
The essential amino acid, methionine, is important for cancer cell growth and metabolism. A growing body of evidence indicates that methionine restriction inhibits cancer cell growth and may enhance the efficacy of chemotherapeutic agents. This review summarizes the efficacy and mechanism of action of methionine restriction on hallmarks of cancer in vitro and in vivo. The review highlights the role of glutathione formation, polyamine synthesis, and methyl group donation as mediators of the effects of methionine restriction on cancer biology. The translational potential of the use of methionine restriction as a personalized nutritional approach for the treatment of patients with cancer is also discussed.
\end{abstract}

Keywords: methionine; cancer; methylation; amino acids; glutathione

\section{Introduction}

Cancer is the second leading cause of death in the United States, with an estimated 1.7 million new cases in the U.S. in 2019 alone [1]. Globally, the amount of cancer-related deaths outnumbered any other disease-related death, rising higher than coronary heart disease, or stroke [2]. Our understanding of cancer's unique programming has led to the definition of the six hallmarks of cancer. These characteristics include cancer cells' ability to (1) maintain proliferative signaling, (2) bypass growth suppressors, (3) resist apoptosis, (4) enable replicative immortality, (5) induce angiogenesis, and (6) initiate invasion and metastasis [3]. Once cancer has metastasized, the risk of mortality increases, making metastatic cancer particularly difficult to treat [4]. The current treatment options for cancer vary based on the type of cancer, as well as progression, and includes chemotherapy, radiation therapy, immunotherapy, and targeted therapy. Traditional chemotherapy has been the primary treatment for cancer based on its ability to inhibit rapidly dividing cancer cells [5]. While this treatment has increased the lifespan of many patients, the toxic effects on normal cells have detrimental health consequences. According to a recent national survey, $48 \%$ of people undergoing chemotherapy reported side effects including pain, nausea, and vomiting, while fatigue was reported in $80 \%$ of patients [6]. Additionally, the efficacy of chemotherapy can be limited due to drug resistance that may occur in some patients after several cycles of treatments [7]. Recently there has been much interest in shifting cancer treatment from cytotoxic non-specific agents to highly selective, mechanism-based therapeutics, thus paving the way for advanced nutritional therapies [8].

The dependence of many tumor cells on an exogenous source of the sulfur amino acid, methionine, [9-11] makes dietary methionine restriction (MR) an exciting potential tool in the treatment of cancer. Proliferation and growth of several types of cancer cells are inhibited by MR, while normal cells are unaffected by limiting methionine as long as homocysteine is present [9]. In addition to inhibiting cancer cell growth, MR has been shown to enhance efficacy of chemotherapy and radiation therapy in animal models [12]. Herein, we provide a review of the literature regarding efficacy and mechanism of action of methionine restriction on cancer cell growth in vitro and in vivo. We 
also provide insight into the translational potential of methionine restriction as a cancer treatment in humans.

\section{Methionine Restriction}

Methionine is an essential amino acid, and as such it must be consumed in the diet to sustain life. Despite consumption of methionine being essential for survival, studies have shown that limiting methionine in the diet of animals or in cell culture media provides metabolic benefits such as decreasing adiposity [13-21], increasing insulin sensitivity [15-17,20-22], decreasing inflammation [23-25], and oxidative stress [26-33], and extending lifespan [34-36]. In fact, rats fed a diet with 80\% less methionine lived $40 \%$ longer than rats fed a control diet [34]. Subsequent studies found that dietary MR was also effective at extending lifespan in outbred mice [35] and several rat strains with different age-related pathologies [36]. The lifespan-extending effects of MR have been attributed to a number of different mechanisms, including MR-induced reductions in oxidative stress [30] and inflammation [23], alterations in autophagy [37], and increases in cardioprotective hormones [15,38,39]. Another mechanism by which MR may extend lifespan is by providing a reduction in cancer incidence and overall reduction in cancer mortality.

The ability of MR to improve insulin sensitivity and reduce adiposity may be directly related to its anti-cancer potential as there are several types of cancer that are closely linked to obesity and insulin resistance [40-43] and the anti-cancer effects of MR may be secondary to its ability to reduce adiposity and increase insulin sensitivity. In mice, eight weeks of dietary MR produced a 3.1-fold increase in whole-body insulin sensitivity and an increase in tissue-specific glucose uptake measured during a hyperinsulinemic-euglycemic clamp [17,22]. Additionally, MR enhanced insulin-stimulated Akt phosphorylation in liver, muscle, and brown and white adipocytes in mice [22]. At least part of the insulin-sensitizing effect of MR can be attributed to its ability to reduce body weight and adiposity. However, limiting media methionine concentrations also enhances insulin signaling in HepG2 cells, indicating cell-autonomous effects of MR [22]. Of note, methionine restriction is effective when the non-essential amino acid, cysteine, is absent from the diet or media. Inclusion of cysteine reverses the effects of MR on metabolism and antioxidant status [16,44,45].

\section{Methionine Metabolism}

While methionine is involved in many biological processes, this review will highlight three major functions of methionine with relevance to cancer biology: (1) glutathione formation, (2) polyamine synthesis, and (3) methyl group donation (Figure 1).

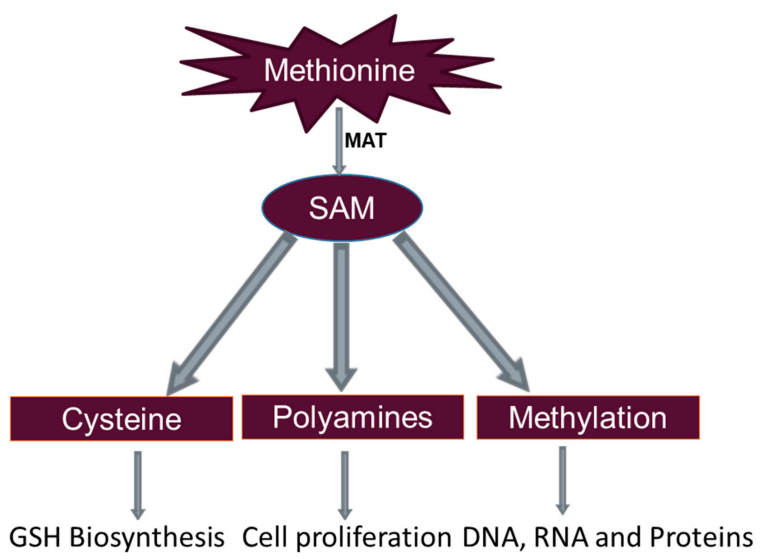

Figure 1. Methionine metabolism and major functions with relevance to GSH biosynthesis, Cell proliferation and methylation. GSH: Glutathione; MAT: Methionine adenosyltransferase; SAM: S-adenosyl methionine. 


\subsection{Glutathione Formation}

Glutathione (GSH) is a thiol antioxidant that scavenges reactive oxygen species (ROS), resulting in the formation of oxidized glutathione (GSSG) [46]. Decreased amounts of GSH and a decreased GSH/GSSG ratio in tissues are biomarkers of oxidative stress [46]. Intracellular ROS can activate the PI3K pathway, which has been linked to increased cancer cell growth [47]. Chronic oxidative stress may lead to chronic inflammation and cancer development and progression [48].

The pathways involved in GSH production are regulated by many factors, including methionine. In the trans-sulfuration pathway, methionine is the precursor for cysteine which is essential for the formation of GSH [49]. Surprisingly, when methionine was restricted by $80 \%$ in the diet of rats, the level of GSH in the blood actually increased due to adaptations in sulfur-amino acid metabolism [31,50]. However, GSH concentrations were reduced in the liver [31,50]. Despite the MR-induced reduction in hepatic GSH, MR does not increase oxidative stress, in part because MR enhances antioxidant capacity and increases proton leak in the liver, likely decreasing ROS production [51]. The ability of MR to increase GSH levels in red blood cells is significant because of the role of GSH in the neutralization of ROS [52]. Several animal studies have shown restricting dietary methionine by just $40 \%$ reduces mitochondrial ROS production in several tissues, resulting in reduced mitochondrial DNA oxidative damage in vivo $[30,53,54]$.

\subsection{Polyamine Synthesis}

Polyamines are small, naturally occurring cations that are essential in preserving chromatin structure, regulating ion-channels, and maintaining membrane stability [55]. Methionine is a precursor for the polyamines, spermidine and spermine. S-adenosylmethionine decarboxylase (SAMDC) is the key enzyme involved in polyamine biosynthesis. The product of its catalytic reaction, decarboxylated S-adenosylmethionine (dcSAM), serves as an aminopropyl donor in the biosynthesis of spermidine and spermine [56]. While spermidine is synthesized in most cells, spermine is specifically formed from the decarboxylation of S-adenosyl methionine by SAMDC in eukaryotic cells. Polyamines play a role in protein synthesis by regulating transcriptional and translational stages [57]. Polyamines are involved in the growth and proliferation of eukaryotic cells. Therefore, during polyamine depletion, there is a disruption in the cell cycle, inducing apoptosis [58,59]. Studies have shown that elevated levels of polyamines are associated with increased tumor growth [57]. Inhibitors of polyamine metabolism, such as alpha-difluoromethylornithine, lead to a reduction in polyamine production, and a disruption of the cell cycle and DNA synthesis in cancer cells [60,61]. In addition, other studies suggest that the mechanism of growth inhibition includes a downregulation of polyamine biosynthesis and the induction of the cyclin-dependent kinase inhibitor, p21 [59,62]. In cancer, there is often a disruption in polyamine metabolism leading to an increase in oxidative damage [56]. Polyamine metabolism is a potential target for treatment of several types of cancers [57]. Given that polyamine synthesis is dependent upon methionine, MR may be a novel approach to inhibit cancer cell growth by downregulating polyamine formation.

\subsection{DNA Methylation}

DNA methylation is one of the most well characterized epigenetic modifications. Methylation takes place on most CpG dinucleotides occurring on 70\% of cytosine bases. Cancer has been associated with both global DNA hypomethylation and gene-specific hypermethylation [63]. Hypermethylation of CpG islands in gene promoter regions may cause aberrant silencing of transcription and is a mechanism for downregulation of tumor-suppressor genes [64]. In fact, CpG island hypermethylation of specific genes is a hallmark in many cancer types $[63,65]$. S-adenosyl methionine (SAM) is the universal methyl donor for the methylation of DNA, RNA, histones, phospholipids, catecholamines, and proteins [66]. The methylation of various biomarkers (TFPI2, SEPT9, GSTP1, MGMT) in the presence of SAM have been shown to cause changes in tumor growth or suppression [67]. Methylation 
is a reversible modification, suggesting that dietary MR has the potential to affect cancer development and progression through modifying DNA methylation patterns.

In general, aging is associated with global DNA hypomethylation despite some regions of specific genes becoming hypermethylated. It has been proposed that methionine metabolism is sensed by DNA methyltransferases that could alter methylation and lifespan [68]. Interestingly, in rodents, dietary methionine restriction has varying effects on global DNA methylation depending on the age of the animal. Twelve weeks of dietary MR increased global DNA methylation in the liver of old (age 1 year at start of intervention) mice, but had no effect on hepatic global DNA methylation in young (age 6 weeks at start of intervention) mice [69]. These data suggest that altered DNA methylation may be an important factor in the health benefits of MR [69].

\section{Methionine Restriction and Cancer}

\subsection{Overview}

In 1959, one of the early studies conducted in methionine restriction evaluated several outcomes produced from diets lacking specific amino acids. The study was conducted on rats fed isocaloric diets that were complete in all amino acids or devoid of one essential amino acid [70]. After transplantation of the Walker tumor, and 10-day preparative diet, rats were divided into different groups. Each group was fed a specific diet with different amino acid compositions for 5 days. While the initial aim of this study was to distinguish between two opposing views on nitrogen balance and amino acid restriction, the results showed a significant reduction in tumor growth in the rats fed diets lacking either methionine, valine, or isoleucine [70].

A subsequent study published in 1974 focused on methionine specifically [71]. This study was conducted on tissue cultures including W-256 (a rat breast cancer cell line), L1210 (a mouse lymphatic leukemia cell line), J111 (a human leukemia cell line), liver epithelial and liver fibroblasts of rats, skin fibroblasts of mice, and human breast and prostate cells that were normal or malignant [71]. The cells were cultured in folic acid- and cyanocobalamin-rich medium that either contained methionine or was methionine-free with a homocysteine supplement. Despite the media containing other methyl donors, the growth of the malignant cells was significantly impaired in the methionine-depleted media, while the normal cell growth was unchanged. These effects were attributed to the ability of normal cells to recycle homocysteine through methionine synthase to supply methionine endogenously. While this is true for normal cells, malignant cells lack the enzyme required to recycle homocysteine therefore giving methionine restriction the capacity to alter cancer cells while maintaining normal, healthy cells [72,73]. This enables the possibility that methionine restriction, as a therapeutic, may be able to specifically target cancer cells, preventing off-target effects on normal cellular processes. The following sections of this review provide an overview of the literature regarding methionine restriction and specific cancer types, including prostate, breast, and colorectal cancers (Table 1).

Table 1. Methionine restriction and cancer biology.

\begin{tabular}{lll}
\hline \multicolumn{1}{c}{ Cancer Model } & \multicolumn{1}{c}{ Effects of Methionine Restriction } & Reference \\
\hline $\begin{array}{l}\text { 23 cancer cell lines: lung, bladder, prostate, cervical, colon, } \\
\text { sarcoma, glioblastoma, melanoma, neuroblastoma, others }\end{array}$ & $\begin{array}{l}11 \text { cell lines are absolutely dependent on } \\
\text { methionine for growth. }\end{array}$ & [10] \\
\hline 21 human patient-derived tumors of various cancer types & $\begin{array}{l}\text { Out of 21 human tumors, five (colon, breast, } \\
\text { ovary, prostate, and a melanoma) were deemed } \\
\text { methionine-dependent based on cell } \\
\text { cycle analysis. }\end{array}$ & {$[11]$} \\
\hline $\begin{array}{l}\text { Tissue cultures of rat breast cancer, mouse lymphatic } \\
\text { leukemia, human monocytic leukemia, rat liver epithelial } \\
\text { cells, rat liver fibroblasts, mouse skin fibroblasts, human } \\
\text { breast fibroblasts, human prostate fibroblasts }\end{array}$ & $\begin{array}{l}\text { Normal cells can grow in methionine-depleted, } \\
\text { homocysteine-supplemented media, while } \\
\text { cancer cells cannot survive. }\end{array}$ & [71] \\
\hline
\end{tabular}


Table 1. Cont.

\begin{tabular}{|c|c|c|}
\hline Cancer Model & Effects of Methionine Restriction & Reference \\
\hline $\begin{array}{l}\text { CNS tumor cell lines, fibroblast, and medulloblastoma } \\
\text { cell lines }\end{array}$ & $\begin{array}{l}\text { MR caused the following: (1) a marked increase } \\
\text { of GADD45 } \alpha \text { and } \gamma \text { in the wt-p53 cell lines } \\
\text { SWB61; (2) an increase in GADD34 and p21 } \\
\text { protein in all of the methionine-dependent lines; } \\
\text { and (3) the induction of MDA7 and } \\
\text { phospho-p38 in DAOY and SWB39, consistent } \\
\text { with marked transcriptional activation of the } \\
\text { former under methionine stress. }\end{array}$ & [72] \\
\hline $\begin{array}{l}\text { Human prostate cancer cell line, primary prostate } \\
\text { epithelial cells }\end{array}$ & $\begin{array}{l}\text { MR synergistically enhances the anti-tumor } \\
\text { effect of 5-FU by depletion of reduced folates, } \\
\text { selective inhibition of thymidylate synthase } \\
\text { (TS), and creation of an imbalanced } \\
\text { nucleotide pool. }\end{array}$ & [74] \\
\hline Human prostate cancer cell line & $\begin{array}{l}\text { MR in DU145 and PC } 3 \text { cells reduces } \\
\text { mitochondrial membrane potential and induces } \\
\text { caspase-dependent and } \\
\text {-independent apoptosis. }\end{array}$ & [75] \\
\hline Human prostate cancer cell line & $\begin{array}{l}\text { MR inhibits phosphorylation but not protein } \\
\text { expression of FAK and ERK in PC } 3 \text { cells. }\end{array}$ & [76] \\
\hline Human prostate cancer cell line & $\begin{array}{l}\text { MR led to an accumulation of the } \\
\text { cyclin-dependent kinase inhibitors p21 and p27. }\end{array}$ & [77] \\
\hline $\begin{array}{l}\text { Human prostate cancer cell line, human cervical carcinoma } \\
\text { cell line }\end{array}$ & $\begin{array}{l}\text { MR induces apoptosis of prostate cancer cells } \\
\text { via the c-Jun N-terminal kinase-mediated } \\
\text { signaling pathway. }\end{array}$ & [78] \\
\hline Human TNBC cell line & $\begin{array}{l}\text { Methionine deprivation increases the sensitivity } \\
\text { to potential cancer drug in triple-negative } \\
\text { breast cancer cells by enhancing TRAIL } \\
\text { receptor-2 expression. }\end{array}$ & [79] \\
\hline Human TNBC cell line and mouse model of TNBC & $\begin{array}{l}\text { Methionine deprivation inhibited the migration } \\
\text { and invasion of cancer cells. In addition, } \\
\text { methionine deprivation reduced the activation } \\
\text { of FAK and the expression of matrix MMP-2 } \\
\text { and MMP-9. }\end{array}$ & [80] \\
\hline Human TNBC cell line and mouse fibroblast & $\begin{array}{l}\text { MR inhibited growth and induced apoptosis in } \\
\text { TNBC cells in a GCN2- and } \\
\text { PERK-independent mechanism. }\end{array}$ & [81] \\
\hline
\end{tabular}

\section{Animal models}

\begin{tabular}{lll}
\hline $\begin{array}{l}\text { Two patient-derived xenograft models of colorectal cancer } \\
\text { and one mouse model of autochthonous } \\
\text { soft-tissue sarcoma }\end{array}$ & $\begin{array}{l}\text { Methionine restriction effectively inhibits tumor } \\
\text { growth in two chemotherapy-resistant } \\
\text { colorectal cancer samples from human patients. } \\
\text { In addition, MR also suppresses tumor } \\
\text { development in a mouse model of } \\
\text { autochthonous soft-tissue sarcoma. }\end{array}$ & [12] \\
\hline $\begin{array}{l}\text { Sprague-Dawley rats with subcutaneously transplanted } \\
\text { Walker tumor }\end{array}$ & $\begin{array}{l}\text { Methionine restriction suppressed } \\
\text { tumor growth. }\end{array}$ & [70] \\
\hline $\begin{array}{l}\text { Transgenic Adenocarcinoma of the Mouse Prostate } \\
\text { (TRAMP) }\end{array}$ & $\begin{array}{l}\text { Methionine restriction inhibits prostatic } \\
\text { intraepithelial neoplasia in TRAMP mice. }\end{array}$ & [82] \\
\hline Human gastric cancer xenograft in nude mice & $\begin{array}{l}\text { Methionine depletion increased the 5-FU } \\
\text { antitumor activity by modulating intratumoral } \\
\text { folate metabolism. }\end{array}$ & [83] \\
\hline Rats with Yoshida Sarcoma & $\begin{array}{l}\text { Methionine deprivation inhibits tumor growth } \\
\text { and metastasis with administration of 5-FU. }\end{array}$ & [84] \\
\hline $\begin{array}{l}\text { Mice injected with human pre-malignant breast epithelial } \\
\text { cell line }\end{array}$ & $\begin{array}{l}\text { Methionine restriction inhibits growth of breast } \\
\text { tumors by increasing cell cycle inhibitors in } \\
\text { nude mice. }\end{array}$ & [85] \\
\hline
\end{tabular}


Table 1. Cont.

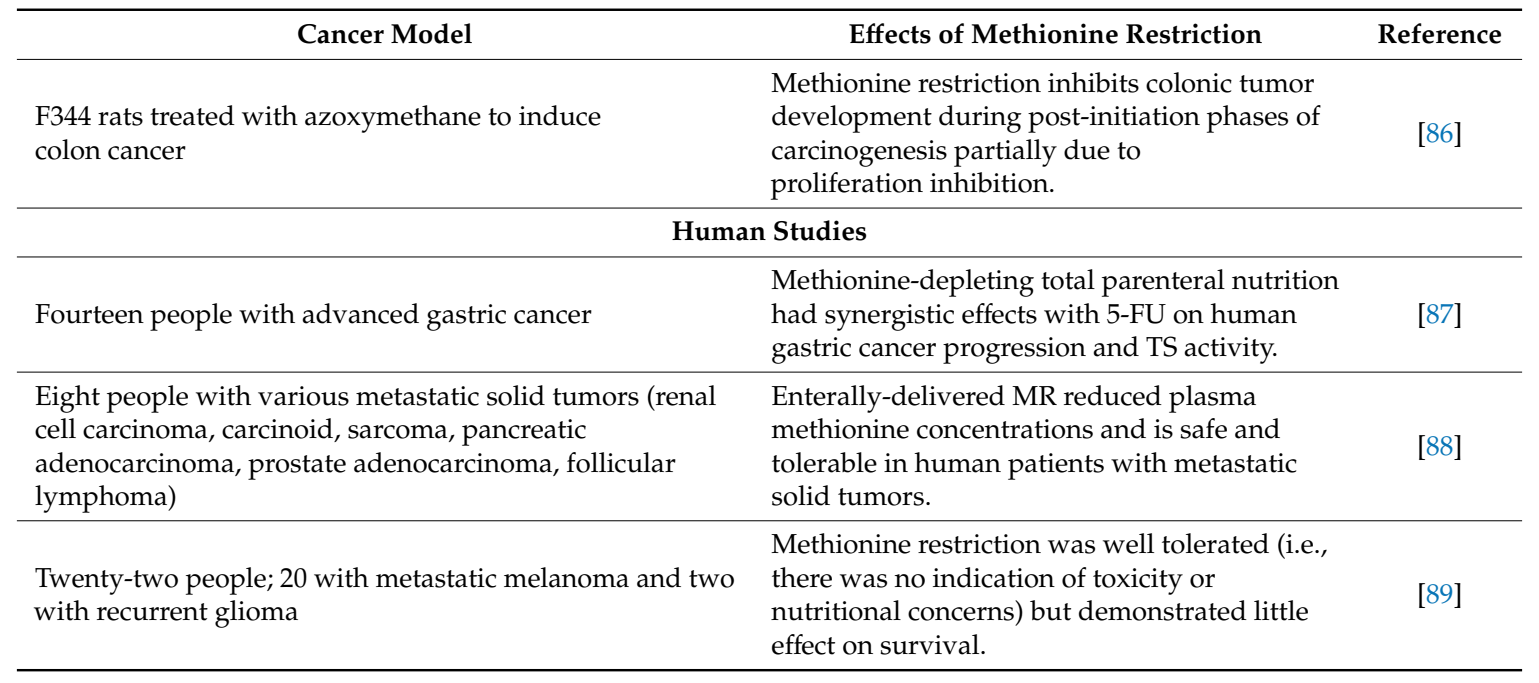

\subsection{Methionine Restriction and Prostate Cancer}

Prostate cancer is the second leading cause of cancer death among adult men in the US and current treatment options include hormonal therapy to reduce testosterone levels, radiation therapy, or surgical procedures [90]. While there are treatment options available for prostate cancer, there are no known interventions to prevent the development of prostate cancer. Using a well-characterized mouse model for prostate cancer (Transgenic Adenocarcinoma of the Mouse Prostate; TRAMP), it was shown that dietary MR inhibits prostate cancer development especially in the anterior and dorsal lobes of the prostate, where the most severe lesions are found [82]. While the mechanism by which MR inhibits prostate cancer development is not known, evidence suggests that MR may work by inhibiting prostate cancer cell proliferation, inhibiting the insulin/IGF-1 axis, or by reducing polyamine synthesis [82]. The cells of the prostate produce high levels of polyamines and inhibition of polyamine synthesis is effective at suppressing tumor growth in prostate cancer [91]. Given the dependence of polyamine synthesis on methionine, the polyamine biosynthetic pathway may be a primary target of MR in prevention and/or treatment of prostate cancer.

Another target of MR in prostate cancer cells is thymidylate synthase (TS). Thymidylate synthase is the enzyme that catalyzes the methylation of deoxyuridylic acid during nucleotide biosynthesis and is thus an important target for cancer treatment. The chemotherapy drug, 5 -fluorouracil (5-fu), inhibits TS activity by disrupting action of TS, causing DNA and RNA damage, making 5-fu an effective and commonly used cancer treatment [74]. However, 5-fu has also been reported to increase TS protein expression, resulting in 5-fu drug resistance [92]. Interestingly, several studies have shown that MR and 5-fu have synergistic anti-cancer effects $[12,83,84,87]$. MR selectively reduces TS activity in prostate cancer cells by $\sim 80 \%$ within $48 \mathrm{~h}$, but does not affect TS activity in normal prostate epithelial cells [74]. Importantly, MR also reduces TS protein expression, potentially explaining the synergy between MR and 5-fu [74]. That MR also reduces TS protein expression may make MR an attractive treatment alongside 5-fu to help combat resistance to 5-fluoruracil.

Methionine restriction has been shown to induce apoptosis in the human prostate cancer cell lines, PC3 and DU145 [75-77]. MR inhibits Raf and Akt oncogenic pathways, while increasing caspase- 9 and the mitochondrial pro-apoptotic protein, Bak $[75,76]$. Restricting media methionine concentrations damages mitochondrial integrity, leading to apoptosis in both prostate cancer cell lines [75,76]. Additionally, energy production was impaired and ROS production was decreased. Caspase-dependent and -independent apoptosis was observed in response to MR [75,76]. Other studies have identified that c-Jun N-terminal kinases (JNK1) is a critical regulator of MR-induced apoptosis in prostate cancer cells [78]. 
In another study, PC-3, DU-145, and LNCaP human prostate cancer cell lines were cultured in complete- or methionine-free media and methionine dependency was evaluated [77]. The results showed that PC-3 is completely methionine-dependent, while DU-145 cells were mildly dependent, and LNCaP cells were almost completely methionine-independent. These data indicate that the responses to methionine restriction vary across different cancers, although MR inhibited growth of all three cancer cell lines [77]. The mechanisms by which MR reduced cancer growth also differed between the cell lines, with MR upregulating p21 and p27 (cell cycle inhibitors that halt cell cycle progression) in LNCaP cells, but only increasing p27 in PC-3 cells [77]. Further, the PC-3 cells began to undergo apoptosis within six days of MR, whereas the LNCaP cells were relatively resistant to MR-induced apoptosis [77]. Together, these data indicate a precision diet such as MR may benefit a subpopulation of patients with prostate cancer.

\subsection{Methionine Restriction and Breast Cancer}

Breast cancer is the second most common form of cancer diagnosed in women. Depending on the type of breast cancer, treatment options include surgery to remove the cancer or the entire breast, chemotherapy, hormone therapy, radiation therapy, and in some cases, targeted therapy drugs or immunotherapy. Breast cancer cells are hormone receptor-positive if they express either (or both) of the estrogen and/or progesterone receptors and are considered HER-2-positive if the breast cancer cells overexpress the protein, HER-2 (human epidermal growth factor receptor 2). If the cells meet none of these criteria, it is triple negative breast cancer (TNBC). TNBC makes up about $16 \%$ of all breast cancer diagnoses [93]. Few studies have examined the efficacy of MR in breast cancer models.

To investigate the effects of MR on breast cancer, a comprehensive study employed MR in a xenograft model for breast cancer, an immortalized human breast cell line, and an invasive breast cancer cell line [85]. In the animal model, athymic nude mice were injected with MCF10AT1 breast cancer cells. The control group was fed a diet containing $0.86 \%$ methionine while the MR group was fed a diet containing $0.12 \%$ methionine for 12 weeks [85]. Methionine restriction inhibited tumor progression in the mice by decreasing cell proliferation and increasing apoptosis [85]. MR increased expression of p21, but not p27, in the mouse mammary gland. Studies in the breast cancer cell line and immortalized breast cell line supported the involvement of p21 in the mechanism of action of MR. Additional mechanisms proposed involved the MR-induced reduction in circulating insulin and IGF1, which have both been linked to tumor growth, and the MR-induced depletion of polyamines [85].

TNBC has fewer treatment options than other forms of breast cancer due to the lack of a response to hormone therapy and drugs that target HER-2. Methionine restriction may provide a way to enhance efficacy of potential treatment options for TNBC. Tumor necrosis factor (TNF)-related apoptosis-inducing ligand (TRAIL) receptor agonists are an exciting possibility for cancer treatment due to their ability to induce apoptosis in cancer cells while having little effect on normal cells. Despite their efficacy in preclinical studies, TRAIL receptor agonists have not been successful in human clinical trials. Methionine deprivation enhances expression of TRAIL-R2 in TNBC cells, but not in normal breast epithelial cells [81]. Further, a methionine-free diet suppresses breast cancer growth and enhances the efficacy of the TRAIL-receptor 2 monoclonal antibody, lexatumumab, in inhibiting breast cancer growth in mice [81]. Studies have identified that out of 10 essential amino acids tested, depletion of methionine elicited the greatest inhibition of migration and invasion of TNBC cells [79]. Together, these data suggest that a combination of TRAIL receptor agonists with a methionine-restricted diet may enhance efficacy of this treatment [81].

Since some studies have shown that MR activates the integrated stress response [80] (a potentially detrimental action), recent studies have been undertaken to determine if blocking the ability of MR to activate the integrated stress response will enhance its efficacy in treating TNBC [94]. MR has been shown to activate two kinases involved in initiating the integrated stress response: general control nonderepressible 2 (GCN2) and protein kinase R-like endoplasmic reticulum kinase (PERK) [16]. It was postulated that blocking either or both of these kinases may enhance efficacy of methionine restriction 
in TNBC [94]. However, when either or both GCN2 and PERK were blocked, MR still initiated the integrated stress response in TNBC cells as evidenced by phosphorylation of eukaryotic initiation factor $2 \alpha(\mathrm{eIF} 2 \alpha)$, the downstream target of these kinases and induction of activating transcription factor 4 (ATF4), a downstream target of eIF2 $\alpha$ [94]. Blocking the action of GCN2 and PERK did not affect the ability of MR to inhibit growth and induce apoptosis in TNBC cells [94]. Elucidating the mechanism by which MR activates the integrated stress response might provide novel targets to enhance efficacy of MR in slowing cancer growth [94].

\subsection{Methionine Restriction and Colorectal Cancer}

Colorectal cancer is the fourth leading cause of cancer-related death in the U.S. The relationship between methionine restriction and colon cancer has been established in tumor prevention and treatment in animal and cell culture models. A recent study evaluated the effects of MR on two patient-derived xenograft (PDX) models of colorectal cancer [12]. Methionine restriction (86\% methionine-restricted diet) was initiated either two weeks before inoculation to determine the effects of MR on cancer prevention, or when the tumor became palpable to test the treatment effects of MR [12]. Initiating MR prior to tumor inoculation resulted in significantly impaired tumor growth in both PDX models. Initiating MR at the time the tumor was palpable significantly reduced tumor growth in one PDX model and tended to reduce tumor growth in the other, but this did not reach statistical significance [12]. Importantly, MR also enhanced efficacy of 5-fluorouracil, a chemotherapeutic drug with great efficacy against colorectal cancer [95], in the PDX model [12].

Inhibition of colon carcinogenesis was investigated using an azoxymethane-induced colon carcinogenesis rat model [86]. F344 rats were fed either control or 80\% methionine-restricted diets for one week and were administered azoxymethane for two weeks to initiate colon carcinogenesis. Ten weeks after initiation of colon carcinogenesis (13 weeks after the start of the study), rats were sacrificed for examination of aberrant crypt foci (ACF) formation in the colon. Dietary MR, when maintained throughout the duration of the study, inhibited formation of large colonic ACF, which are well correlated with tumor formation, by over $80 \%$ [86]. Interestingly, consuming the MR diet for just the post-initiation period, had similar effects of consuming MR throughout the full 13-week study, with a $98 \%$ inhibition of large ACF formation in the colon. However, consuming the MR diet for just the initiation period (one week prior to- and two weeks during the azoxymethane treatment) had little effect on ACF formation, suggesting that the greatest inhibitory effects of MR on colon carcinogenesis occur primarily during the post-initiation phases [86]. MR-induced reduction in cell proliferation was hypothesized as a possible mechanism based on the $12 \%$ reduction in proliferation markers, BrdU and PCNA [86]. This study displayed MR's inhibitory effect on colon carcinogenesis, presenting MR as a preventative treatment [86].

\section{Translational Potential of Methionine Restriction as Treatment for People with Cancer}

A growing body of literature conducted in cell culture and animal models indicates efficacy and safety of methionine restriction, alone or in combination with standard cancer therapies, as a treatment or preventative for a number of different cancers. However, there have been few studies investigating the anti-cancer potential of MR in humans. The provision of an MR diet to humans usually involves the use of an elemental amino acid medical beverage lacking methionine to ensure patients obtain desired quantities of protein since other food sources of protein must be limited to ensure adequate restriction of dietary methionine. A feasibility study published in 2002 established that methionine restriction, provided enterally, for an average of 17 weeks is safe and feasible in patients with advanced metastatic cancer ( $n=8$ subjects analyzed) [88]. A seven day study indicated that short-term MR, achieved through total parenteral nutrition, enhanced efficacy of 5-fluorouracil in patients with advanced gastric cancer [87]. Cystemustine is a drug that is most effective against human glioma and melanoma [96]. A phase II clinical trial of 22 patients (20 with metastatic melanoma and two with recurrent glioma) evaluated efficacy and safety of methionine restriction combined with conventional cystemustine 
treatment [89]. In this study, patients consumed a methionine-free diet for one day every two weeks during the two-month cystemustine treatment period [89]. The authors confirmed the feasibility of implementing a methionine-restricted diet in patients with advanced cancer and showed that following this MR feeding regimen did not negatively affect the patients' nutritional status, as evidenced by stable body weights and relatively stable serum albumin and prealbumin concentrations [89]. However, the inclusion of MR once every two weeks had no clinically meaningful effects on survival [89].

The evidence produced from the limited clinical trials of MR in cancer patients, bolstered by the robust evidence of efficacy of MR in preclinical rodent and cell culture studies, potentiates MR as an exciting tool in cancer treatment. Additional large-scale clinical trials are needed to identify optimal treatment regimens of MR alone or in combination with standard care in different types and stages of cancer.

\section{Conclusions}

Dietary methionine restriction reduces circulating methionine concentrations in most human and animal studies within just days of consuming the diets. These data suggest that the MR-induced inhibition of cancer progression is due, at least in part, to cell-autonomous effects on tumors [12]. There are many alterations in methionine metabolism associated with cancer and understanding how dietary methionine affects cancer could yield important insights into novel treatment approaches [97]. Preclinical studies indicate that MR is effective when implemented in both prevention and treatment contexts and enhances efficacy of some standard cancer therapies. Studies have shown that MR exhibits anti-cancer activities in many types and stages of cancer. Studies identifying optimal degrees of methionine restriction are warranted due to the fact that MR is usually accompanied by weight loss, a symptom typically associated with poorer prognosis in cancer patients. To understand whether the preclinical successes of MR will translate to humans, larger scale clinical trials combining dietary methionine restriction with current standard treatment approaches in people with cancer are needed.

Progress has been made in identifying the mechanism by which MR inhibits cancer growth. Inhibition of thymidylate synthase activity, reduced polyamine biosynthesis, induction of apoptosis, and alterations in DNA methylation and glutathione formation are likely targets of MR, depending on the type of cancer. As the field moves toward implementation of MR in people with cancer, molecular studies into the mechanism of action of MR using cell culture and animal models will be important. For instance, identifying the mechanism by which MR inhibits thymidylate synthase activity and protein expression could yield a novel drug target. Given that normal cells can synthesize sufficient methionine for growth, but many cancer cells require exogenous methionine for survival, methionine restriction has potential as a cancer therapeutic [98]. Elucidating the signaling pathways and molecular mechanisms of methionine restriction could improve current therapeutic options and lead to the development of new targeted treatment options for people with cancer.

Author Contributions: D.W. and K.H. planned and wrote the manuscript. D.W. and X.J. provided intellectual oversight and reviewed manuscript. All authors have read and agreed to the published version of the manuscript.

Funding: This research was funded by FAMRI foundation YFEL141014 to X.J.

Conflicts of Interest: The authors declare no conflict of interest.

\section{References}

1. Siegel, R.L.; Miller, K.D.; Jemal, A. Cancer statistics, 2019. CA A Cancer J. Clin. 2019, 69, 7-34. [CrossRef] [PubMed]

2. Ferlay, J.; Soerjomataram, I.; Dikshit, R.; Eser, S.; Mathers, C.; Rebelo, M.; Parkin, D.M.; Forman, D.; Bray, F. Cancer incidence and mortality worldwide: Sources, methods and major patterns in GLOBOCAN 2012. Int. J. Cancer 2015, 136, 359-386. [CrossRef] [PubMed]

3. Hanahan, D.; Weinberg, R.A. Hallmarks of cancer: The next generation. Cell 2011, 144, 646-674. [CrossRef] [PubMed] 
4. Lee, S.Y.; Jeong, E.K.; Ju, M.K.; Jeon, H.M.; Kim, M.Y.; Kim, C.H.; Park, H.G.; Han, S.I.; Kang, H.S. Induction of metastasis, cancer stem cell phenotype, and oncogenic metabolism in cancer cells by ionizing radiation. Mol. Cancer 2017, 16, 10. [CrossRef] [PubMed]

5. Khamisipour, G.; Jadidi-Niaragh, F.; Jahromi, A.S.; Zandi, K.; Hojjat-Farsangi, M. Mechanisms of tumor cell resistance to the current targeted-therapy agents. Tumour Biol. 2016, 37, 10021-10039. [CrossRef]

6. Henry, D.H.; Viswanathan, H.N.; Elkin, E.P.; Traina, S.; Wade, S.; Cella, D. Symptoms and treatment burden associated with cancer treatment: Results from a cross-sectional national survey in the U.S. Supportive Care Cancer 2008, 16, 791-801. [CrossRef]

7. Kuczynski, E.A.; Sargent, D.J.; Grothey, A.; Kerbel, R.S. Drug rechallenge and treatment beyond progression-implications for drug resistance. Nat. Rev. Clin. Oncol. 2013, 10, 571-587. [CrossRef]

8. Vanneman, M.; Dranoff, G. Combining immunotherapy and targeted therapies in cancer treatment. Nat. Rev. Cancer 2012, 12, 237-251. [CrossRef]

9. Cellarier, E.; Durando, X.; Vasson, M.P.; Farges, M.C.; Demiden, A.; Maurizis, J.C.; Madelmont, J.C.; Chollet, P. Methionine dependency and cancer treatment. Cancer Treat Rev. 2003, 29, 489-499. [CrossRef]

10. Mecham, J.O.; Rowitch, D.; Wallace, C.D.; Stern, P.H.; Hoffman, R.M. The metabolic defect of methionine dependence occurs frequently in human tumor cell lines. Biochem. Biophys. Res. Commun. 1983, 117, 429-434. [CrossRef]

11. Guo, H.Y.; Herrera, H.; Groce, A.; Hoffman, R.M. Expression of the biochemical defect of methionine dependence in fresh patient tumors in primary histoculture. Cancer Res. 1993, 53, 2479-2483. [PubMed]

12. Gao, X.; Sanderson, S.M.; Dai, Z.; Reid, M.A.; Cooper, D.E.; Lu, M.; Richie, J.P., Jr.; Ciccarella, A.; Calcagnotto, A.; Mikhael, P.G.; et al. Dietary methionine influences therapy in mouse cancer models and alters human metabolism. Nature 2019, 572, 397-401. [CrossRef] [PubMed]

13. Orgeron, M.L.; Stone, K.P.; Wanders, D.; Cortez, C.C.; Van, N.T.; Gettys, T.W. The impact of dietary methionine restriction on biomarkers of metabolic health. Prog. Mol. Biol. Transl. Sci. 2014, 121, 351-376. [CrossRef] [PubMed]

14. Wanders, D.; Forney, L.A.; Stone, K.P.; Hasek, B.E.; Johnson, W.D.; Gettys, T.W. The Components of Age-Dependent Effects of Dietary Methionine Restriction on Energy Balance in Rats. Obesity 2018, 26, 740-746. [CrossRef] [PubMed]

15. Wanders, D.; Forney, L.A.; Stone, K.P.; Burk, D.H.; Pierse, A.; Gettys, T.W. FGF21 Mediates the Thermogenic and Insulin-Sensitizing Effects of Dietary Methionine Restriction but Not Its Effects on Hepatic Lipid Metabolism. Diabetes 2017, 66, 858-867. [CrossRef]

16. Wanders, D.; Stone, K.P.; Forney, L.A.; Cortez, C.C.; Dille, K.N.; Simon, J.; Xu, M.; Hotard, E.C.; Nikonorova, I.A.; Pettit, A.P.; et al. Role of GCN2-Independent Signaling Through a Noncanonical PERK/NRF2 Pathway in the Physiological Responses to Dietary Methionine Restriction. Diabetes 2016, 65, 1499-1510. [CrossRef]

17. Wanders, D.; Burk, D.H.; Cortez, C.C.; Van, N.T.; Stone, K.P.; Baker, M.; Mendoza, T.; Mynatt, R.L.; Gettys, T.W. $\mathrm{UCP} 1$ is an essential mediator of the effects of methionine restriction on energy balance but not insulin sensitivity. FASEB J. 2015, 29, 2603-2615. [CrossRef]

18. Ables, G.P.; Johnson, J.E. Pleiotropic responses to methionine restriction. Exp. Gerontol. 2017, 94, 83-88. [CrossRef]

19. Ables, G.P.; Hens, J.R.; Nichenametla, S.N. Methionine restriction beyond life-span extension. Ann. N. Y. Acad. Sci. 2016, 1363, 68-79. [CrossRef]

20. Ables, G.P.; Perrone, C.E.; Orentreich, D.; Orentreich, N. Methionine-restricted C57BL/6J mice are resistant to diet-induced obesity and insulin resistance but have low bone density. PLoS ONE 2012, 7, e51357. [CrossRef]

21. Malloy, V.L.; Krajcik, R.A.; Bailey, S.J.; Hristopoulos, G.; Plummer, J.D.; Orentreich, N. Methionine restriction decreases visceral fat mass and preserves insulin action in aging male Fischer 344 rats independent of energy restriction. Aging Cell 2006, 5, 305-314. [CrossRef] [PubMed]

22. Stone, K.P.; Wanders, D.; Orgeron, M.; Cortez, C.C.; Gettys, T.W. Mechanisms of increased in vivo insulin sensitivity by dietary methionine restriction in mice. Diabetes 2014, 63, 3721-3733. [CrossRef] [PubMed]

23. Wanders, D.; Ghosh, S.; Stone, K.P.; Van, N.T.; Gettys, T.W. Transcriptional impact of dietary methionine restriction on systemic inflammation: Relevance to biomarkers of metabolic disease during aging. Biofactors 2014, 40, 13-26. [CrossRef] [PubMed] 
24. Barcena, C.; Quiros, P.M.; Durand, S.; Mayoral, P.; Rodriguez, F.; Caravia, X.M.; Marino, G.; Garabaya, C.; Fernandez-Garcia, M.T.; Kroemer, G.; et al. Methionine Restriction Extends Lifespan in Progeroid Mice and Alters Lipid and Bile Acid Metabolism. Cell Rep. 2018, 24, 2392-2403. [CrossRef]

25. Sharma, S.; Dixon, T.; Jung, S.; Graff, E.C.; Forney, L.A.; Gettys, T.W.; Wanders, D. Dietary Methionine Restriction Reduces Inflammation Independent of FGF21 Action. Obesity 2019, 27, 1305-1313. [CrossRef]

26. Martinez, Y.; Li, X.; Liu, G.; Bin, P.; Yan, W.; Mas, D.; Valdivie, M.; Hu, C.A.; Ren, W.; Yin, Y. The role of methionine on metabolism, oxidative stress, and diseases. Amino Acids 2017, 49, 2091-2098. [CrossRef]

27. Liu, G.; Yu, L.; Fang, J.; Hu, C.A.; Yin, J.; Ni, H.; Ren, W.; Duraipandiyan, V.; Chen, S.; Al-Dhabi, N.A.; et al. Methionine restriction on oxidative stress and immune response in dss-induced colitis mice. Oncotarget 2017, 8, 44511-44520. [CrossRef]

28. Yang, Y.; Ji, Y.; Wu, G.; Sun, K.; Dai, Z.; Wu, Z. Dietary L-methionine restriction decreases oxidative stress in porcine liver mitochondria. Exp. Gerontol. 2015, 65, 35-41. [CrossRef]

29. Yang, Y.; Wang, Y.; Sun, J.; Zhang, J.; Guo, H.; Shi, Y.; Cheng, X.; Tang, X.; Le, G. Dietary methionine restriction reduces hepatic steatosis and oxidative stress in high-fat-fed mice by promoting H2S production. Food Funct. 2019, 10, 61-77. [CrossRef]

30. Sanchez-Roman, I.; Barja, G. Regulation of longevity and oxidative stress by nutritional interventions: Role of methionine restriction. Exp. Gerontol. 2013, 48, 1030-1042. [CrossRef]

31. Maddineni, S.; Nichenametla, S.; Sinha, R.; Wilson, R.P.; Richie, J.P., Jr. Methionine restriction affects oxidative stress and glutathione-related redox pathways in the rat. Exp. Biol. Med. (Maywood) 2013, 238, 392-399. [CrossRef] [PubMed]

32. Pamplona, R.; Barja, G. Mitochondrial oxidative stress, aging and caloric restriction: The protein and methionine connection. Biochim. Biophys. Acta 2006, 1757, 496-508. [CrossRef] [PubMed]

33. Caro, P.; Gomez, J.; Lopez-Torres, M.; Sanchez, I.; Naudi, A.; Jove, M.; Pamplona, R.; Barja, G. Forty percent and eighty percent methionine restriction decrease mitochondrial ROS generation and oxidative stress in rat liver. Biogerontology 2008, 9, 183-196. [CrossRef]

34. Orentreich, N.; Matias, J.R.; DeFelice, A.; Zimmerman, J.A. Low methionine ingestion by rats extends life span. J. Nutr. 1993, 123, 269-274. [CrossRef]

35. Miller, R.A.; Buehner, G.; Chang, Y.; Harper, J.M.; Sigler, R.; Smith-Wheelock, M. Methionine-deficient diet extends mouse lifespan, slows immune and lens aging, alters glucose, T4, IGF-I and insulin levels, and increases hepatocyte MIF levels and stress resistance. Aging Cell 2005, 4, 119-125. [CrossRef]

36. Zimmerman, J.A.; Malloy, V.; Krajcik, R.; Orentreich, N. Nutritional control of aging. Exp. Gerontol. 2003, 38, 47-52. [CrossRef]

37. Ruckenstuhl, C.; Netzberger, C.; Entfellner, I.; Carmona-Gutierrez, D.; Kickenweiz, T.; Stekovic, S.; Gleixner, C.; Schmid, C.; Klug, L.; Sorgo, A.G.; et al. Lifespan extension by methionine restriction requires autophagy-dependent vacuolar acidification. PLoS Genet. 2014, 10, e1004347. [CrossRef] [PubMed]

38. Lee, B.C.; Kaya, A.; Gladyshev, V.N. Methionine restriction and life-span control. Ann. N. Y. Acad. Sci. 2016, 1363, 116-124. [CrossRef] [PubMed]

39. Ables, G.P.; Ouattara, A.; Hampton, T.G.; Cooke, D.; Perodin, F.; Augie, I.; Orentreich, D.S. Dietary methionine restriction in mice elicits an adaptive cardiovascular response to hyperhomocysteinemia. Sci. Rep. 2015, 5, 8886. [CrossRef] [PubMed]

40. Iyengar, N.M.; Gucalp, A.; Dannenberg, A.J.; Hudis, C.A. Obesity and Cancer Mechanisms: Tumor Microenvironment and Inflammation. J. Clin. Oncol. 2016, 34, 4270-4276. [CrossRef]

41. Larsson, S.C.; Wolk, A. Overweight, obesity and risk of liver cancer: A meta-analysis of cohort studies. Br. J. Cancer 2007, 97, 1005-1008. [CrossRef] [PubMed]

42. Neuhouser, M.L.; Aragaki, A.K.; Prentice, R.L.; Manson, J.E.; Chlebowski, R.; Carty, C.L.; Ochs-Balcom, H.M.; Thomson, C.A.; Caan, B.J.; Tinker, L.F.; et al. Overweight, Obesity, and Postmenopausal Invasive Breast Cancer Risk: A Secondary Analysis of the Women's Health Initiative Randomized Clinical Trials. JAMA Oncol. 2015, 1, 611-621. [CrossRef] [PubMed]

43. Bardou, M.; Barkun, A.N.; Martel, M. Obesity and colorectal cancer. Gut 2013, 62, 933-947. [CrossRef] [PubMed]

44. Elshorbagy, A.K.; Valdivia-Garcia, M.; Mattocks, D.A.; Plummer, J.D.; Smith, A.D.; Drevon, C.A.; Refsum, H.; Perrone, C.E. Cysteine supplementation reverses methionine restriction effects on rat adiposity: Significance of stearoyl-coenzyme A desaturase. J. Lipid. Res. 2011, 52, 104-112. [CrossRef] [PubMed] 
45. Gomez, A.; Gomez, J.; Lopez Torres, M.; Naudi, A.; Mota-Martorell, N.; Pamplona, R.; Barja, G. Cysteine dietary supplementation reverses the decrease in mitochondrial ROS production at complex I induced by methionine restriction. J. Bioenerg. Biomembr. 2015, 47, 199-208. [CrossRef]

46. Janssen-Heininger, Y.M.; Nolin, J.D.; Hoffman, S.M.; van der Velden, J.L.; Tully, J.E.; Lahue, K.G.; Abdalla, S.T.; Chapman, D.G.; Reynaert, N.L.; van der Vliet, A.; et al. Emerging mechanisms of glutathione-dependent chemistry in biology and disease. J. Cell. Biochem. 2013, 114, 1962-1968. [CrossRef]

47. Koundouros, N.; Poulogiannis, G. Phosphoinositide 3-Kinase/Akt Signaling and Redox Metabolism in Cancer. Front. Oncol. 2018, 8, 160. [CrossRef]

48. Chai, E.Z.; Siveen, K.S.; Shanmugam, M.K.; Arfuso, F.; Sethi, G. Analysis of the intricate relationship between chronic inflammation and cancer. Biochem. J. 2015, 468, 1-15. [CrossRef]

49. Lu, S.C. Glutathione synthesis. Biochim. Biophys. Acta 2013, 1830, 3143-3153. [CrossRef]

50. Richie, J.P., Jr.; Leutzinger, Y.; Parthasarathy, S.; Malloy, V.; Orentreich, N.; Zimmerman, J.A. Methionine restriction increases blood glutathione and longevity in F344 rats. FASEB J. 1994, 8, 1302-1307. [CrossRef]

51. Tamanna, N.; Kroeker, K.; Braun, K.; Banh, S.; Treberg, J.R. The effect of short-term methionine restriction on glutathione synthetic capacity and antioxidant responses at the whole tissue and mitochondrial level in the rat liver. Exp. Gerontol. 2019, 127, 110712. [CrossRef] [PubMed]

52. Estrela, J.M.; Ortega, A.; Mena, S.; Sirerol, J.A.; Obrador, E. Glutathione in metastases: From mechanisms to clinical applications. Crit. Rev. Clin. Lab. Sci. 2016, 53, 253-267. [CrossRef] [PubMed]

53. Sanchez-Roman, I.; Gomez, A.; Gomez, J.; Suarez, H.; Sanchez, C.; Naudi, A.; Ayala, V.; Portero-Otin, M.; Lopez-Torres, M.; Pamplona, R.; et al. Forty percent methionine restriction lowers DNA methylation, complex I ROS generation, and oxidative damage to mtDNA and mitochondrial proteins in rat heart. $J$. Bioenerg. Biomembr. 2011, 43, 699-708. [CrossRef] [PubMed]

54. Caro, P.; Gomez, J.; Sanchez, I.; Naudi, A.; Ayala, V.; Lopez-Torres, M.; Pamplona, R.; Barja, G. Forty percent methionine restriction decreases mitochondrial oxygen radical production and leak at complex I during forward electron flow and lowers oxidative damage to proteins and mitochondrial DNA in rat kidney and brain mitochondria. Rejuvenation Res. 2009, 12, 421-434. [CrossRef] [PubMed]

55. Nowotarski, S.L.; Woster, P.M.; Casero, R.A., Jr. Polyamines and cancer: Implications for chemotherapy and chemoprevention. Expert Rev. Mol. Med. 2013, 15, 3. [CrossRef]

56. Lee, M.M.; Lee, S.H.; Park, K.Y. Characterization and expression of two members of the S-adenosylmethionine decarboxylase gene family in carnation flower. Plant Mol. Biol. 1997, 34, 371-382. [CrossRef]

57. Thomas, T.; Thomas, T.J. Polyamines in cell growth and cell death: Molecular mechanisms and therapeutic applications. Cell. Mol. Life Sci. 2001, 58, 244-258. [CrossRef]

58. Morgan, D.M. Polyamines. An overview. Mol. Biotechnol. 1999, 11, 229-250. [CrossRef]

59. Thomas, T.; Balabhadrapathruni, S.; Gardner, C.R.; Hong, J.; Faaland, C.A.; Thomas, T.J. Effects of epidermal growth factor on MDA-MB-468 breast cancer cells: Alterations in polyamine biosynthesis and the expression of p21/CIP1/WAF1. J. Cell. Physiol. 1999, 179, 257-266. [CrossRef]

60. Battaglia, V.; DeStefano Shields, C.; Murray-Stewart, T.; Casero, R.A., Jr. Polyamine catabolism in carcinogenesis: Potential targets for chemotherapy and chemoprevention. Amino Acids 2014, 46, 511-519. [CrossRef]

61. Ray, R.M.; Zimmerman, B.J.; McCormack, S.A.; Patel, T.B.; Johnson, L.R. Polyamine depletion arrests cell cycle and induces inhibitors p21(Waf1/Cip1), p27(Kip1), and p53 in IEC-6 cells. Am. J. Physiol. 1999, 276, 684-691. [CrossRef] [PubMed]

62. Thomas, T.; Thomas, T.J. Regulation of cyclin B1 by estradiol and polyamines in MCF-7 breast cancer cells. Cancer Res. 1994, 54, 1077-1084. [PubMed]

63. Kulis, M.; Esteller, M. DNA methylation and cancer. Adv. Genet. 2010, 70, 27-56. [CrossRef] [PubMed]

64. Herman, J.G.; Baylin, S.B. Gene silencing in cancer in association with promoter hypermethylation. N. Engl. J. Med. 2003, 349, 2042-2054. [CrossRef]

65. Paz, M.F.; Fraga, M.F.; Avila, S.; Guo, M.; Pollan, M.; Herman, J.G.; Esteller, M. A systematic profile of DNA methylation in human cancer cell lines. Cancer Res. 2003, 63, 1114-1121.

66. Landgraf, B.J.; McCarthy, E.L.; Booker, S.J. Radical S-Adenosylmethionine Enzymes in Human Health and Disease. Annu. Rev. Biochem. 2016, 85, 485-514. [CrossRef]

67. Fukushige, S.; Horii, A. DNA methylation in cancer: A gene silencing mechanism and the clinical potential of its biomarkers. Tohoku J. Exp. Med. 2013, 229, 173-185. [CrossRef] 
68. Parkhitko, A.A.; Jouandin, P.; Mohr, S.E.; Perrimon, N. Methionine metabolism and methyltransferases in the regulation of aging and lifespan extension across species. Aging Cell 2019, 18, e13034. [CrossRef]

69. Mattocks, D.A.; Mentch, S.J.; Shneyder, J.; Ables, G.P.; Sun, D.; Richie, J.P., Jr.; Locasale, J.W.; Nichenametla, S.N. Short term methionine restriction increases hepatic global DNA methylation in adult but not young male C57BL/6J mice. Exp. Gerontol. 2017, 88, 1-8. [CrossRef]

70. Sugimura, T.; Birnbaum, S.M.; Winitz, M.; Greenstein, J.P. Quantitative nutritional studies with water-soluble, chemically defined diets. VIII. The forced feeding of diets each lacking in one essential amino acid. Arch. Biochem. Biophys. 1959, 81, 448-455. [CrossRef]

71. Halpern, B.C.; Clark, B.R.; Hardy, D.N.; Halpern, R.M.; Smith, R.A. The effect of replacement of methionine by homocystine on survival of malignant and normal adult mammalian cells in culture. Proc. Natl. Acad. Sci. USA 1974, 71, 1133-1136. [CrossRef] [PubMed]

72. Kokkinakis, D.M.; Liu, X.; Chada, S.; Ahmed, M.M.; Shareef, M.M.; Singha, U.K.; Yang, S.; Luo, J. Modulation of gene expression in human central nervous system tumors under methionine deprivation-induced stress. Cancer Res. 2004, 64, 7513-7525. [CrossRef]

73. Cavuoto, P.; Fenech, M.F. A review of methionine dependency and the role of methionine restriction in cancer growth control and life-span extension. Cancer Treat. Rev. 2012, 38, 726-736. [CrossRef] [PubMed]

74. Lu, S.; Chen, G.L.; Ren, C.; Kwabi-Addo, B.; Epner, D.E. Methionine restriction selectively targets thymidylate synthase in prostate cancer cells. Biochem. Pharmacol. 2003, 66, 791-800. [CrossRef]

75. Fu, Y.M.; Zhang, H.; Ding, M.; Li, Y.Q.; Fu, X.; Yu, Z.X.; Meadows, G.G. Selective amino acid restriction targets mitochondria to induce apoptosis of androgen-independent prostate cancer cells. J. Cell. Physiol. 2006, 209, 522-534. [CrossRef] [PubMed]

76. Fu, Y.M.; Yu, Z.X.; Li, Y.Q.; Ge, X.; Sanchez, P.J.; Fu, X.; Meadows, G.G. Specific amino acid dependency regulates invasiveness and viability of androgen-independent prostate cancer cells. Nutr. Cancer 2003, 45, 60-73. [CrossRef] [PubMed]

77. Lu, S.; Epner, D.E. Molecular mechanisms of cell cycle block by methionine restriction in human prostate cancer cells. Nutr. Cancer 2000, 38, 123-130. [CrossRef]

78. Lu, S.; Hoestje, S.M.; Choo, E.M.; Epner, D.E. Methionine restriction induces apoptosis of prostate cancer cells via the c-Jun N-terminal kinase-mediated signaling pathway. Cancer Lett. 2002, 179, 51-58. [CrossRef]

79. Jeon, H.; Kim, J.H.; Lee, E.; Jang, Y.J.; Son, J.E.; Kwon, J.Y.; Lim, T.G.; Kim, S.; Park, J.H.; Kim, J.E.; et al. Methionine deprivation suppresses triple-negative breast cancer metastasis in vitro and in vivo. Oncotarget 2016, 7, 67223-67234. [CrossRef]

80. Jonsson, W.O.; Margolies, N.S.; Anthony, T.G. Dietary Sulfur Amino Acid Restriction and the Integrated Stress Response: Mechanistic Insights. Nutrients 2019, 11. [CrossRef]

81. Strekalova, E.; Malin, D.; Good, D.M.; Cryns, V.L. Methionine Deprivation Induces a Targetable Vulnerability in Triple-Negative Breast Cancer Cells by Enhancing TRAIL Receptor-2 Expression. Clin. Cancer Res. 2015, 21, 2780-2791. [CrossRef] [PubMed]

82. Sinha, R.; Cooper, T.K.; Rogers, C.J.; Sinha, I.; Turbitt, W.J.; Calcagnotto, A.; Perrone, C.E.; Richie, J.P., Jr. Dietary methionine restriction inhibits prostatic intraepithelial neoplasia in TRAMP mice. Prostate 2014, 74, 1663-1673. [CrossRef] [PubMed]

83. Hoshiya, Y.; Kubota, T.; Inada, T.; Kitajima, M.; Hoffman, R.M. Methionine-depletion modulates the efficacy of 5-fluorouracil in human gastric cancer in nude mice. Anticancer Res. 1997, 17, 4371-4375. [PubMed]

84. Goseki, N.; Endo, M.; Onodera, T.; Kosaki, G. Anti-tumor effect of L-methionine-deprived total parenteral nutrition with 5-fluorouracil administration on Yoshida sarcoma-bearing rats. Ann. Surg. 1991, 214, 83-88. [CrossRef] [PubMed]

85. Hens, J.R.; Sinha, I.; Perodin, F.; Cooper, T.; Sinha, R.; Plummer, J.; Perrone, C.E.; Orentreich, D. Methionine-restricted diet inhibits growth of MCF10AT1-derived mammary tumors by increasing cell cycle inhibitors in athymic nude mice. BMC Cancer 2016, 16, 349. [CrossRef] [PubMed]

86. Komninou, D.; Leutzinger, Y.; Reddy, B.S.; Richie, J.P., Jr. Methionine restriction inhibits colon carcinogenesis. Nutr. Cancer 2006, 54, 202-208. [CrossRef] [PubMed]

87. Goseki, N.; Yamazaki, S.; Shimojyu, K.; Kando, F.; Maruyama, M.; Endo, M.; Koike, M.; Takahashi, H. Synergistic effect of methionine-depleting total parenteral nutrition with 5-fluorouracil on human gastric cancer: A randomized, prospective clinical trial. Jpn. J. Cancer Res. 1995, 86, 484-489. [CrossRef] 
88. Epner, D.E.; Morrow, S.; Wilcox, M.; Houghton, J.L. Nutrient intake and nutritional indexes in adults with metastatic cancer on a phase I clinical trial of dietary methionine restriction. Nutr. Cancer 2002, 42, 158-166. [CrossRef]

89. Thivat, E.; Farges, M.C.; Bacin, F.; D’Incan, M.; Mouret-Reynier, M.A.; Cellarier, E.; Madelmont, J.C.; Vasson, M.P.; Chollet, P.; Durando, X. Phase II trial of the association of a methionine-free diet with cystemustine therapy in melanoma and glioma. Anticancer Res. 2009, 29, 5235-5240.

90. Mazzucchelli, R.; Scarpelli, M.; Lopez-Beltran, A.; Cheng, L.; Di Primio, R.; Montironi, R. Treatment effects in prostate cancer following traditional and emerging therapies. Int. J. Immunopathol. Pharmacol. 2013, 26, 291-298. [CrossRef]

91. Meyskens, F.L., Jr.; Simoneau, A.R.; Gerner, E.W. Chemoprevention of prostate cancer with the polyamine synthesis inhibitor difluoromethylornithine. Recent Results Cancer Res. 2014, 202, 115-120. [CrossRef] [PubMed]

92. Ahn, J.Y.; Lee, J.S.; Min, H.Y.; Lee, H.Y. Acquired resistance to 5-fluorouracil via HSP90/Src-mediated increase in thymidylate synthase expression in colon cancer. Oncotarget 2015, 6, 32622-32633. [CrossRef] [PubMed]

93. Blows, F.M.; Driver, K.E.; Schmidt, M.K.; Broeks, A.; van Leeuwen, F.E.; Wesseling, J.; Cheang, M.C.; Gelmon, K.; Nielsen, T.O.; Blomqvist, C.; et al. Subtyping of breast cancer by immunohistochemistry to investigate a relationship between subtype and short and long term survival: A collaborative analysis of data for 10,159 cases from 12 studies. PLoS Med. 2010, 7, e1000279. [CrossRef] [PubMed]

94. Rajanala, S.H.; Ringquist, R.; Cryns, V.L. Methionine restriction activates the integrated stress response in triple-negative breast cancer cells by a GCN2- and PERK-independent mechanism. Am. J. Cancer Res. 2019, 9, 1766-1775. [PubMed]

95. Longley, D.B.; Harkin, D.P.; Johnston, P.G. 5-fluorouracil: Mechanisms of action and clinical strategies. Nat. Rev. Cancer 2003, 3, 330-338. [CrossRef]

96. Cellarier, E.; Terret, C.; Labarre, P.; Ouabdesselam, R.; Cure, H.; Marchenay, C.; Maurizis, J.C.; Madelmont, J.C.; Cholle, P.; Armand, J.P. Pharmacokinetic study of cystemustine, administered on a weekly schedule in cancer patients. Ann. Oncol. 2002, 13, 760-769. [CrossRef]

97. Sanderson, S.M.; Gao, X.; Dai, Z.; Locasale, J.W. Methionine metabolism in health and cancer: A nexus of diet and precision medicine. Nat. Rev. Cancer 2019, 19, 625-637. [CrossRef]

98. Chaturvedi, S.; Hoffman, R.M.; Bertino, J.R. Exploiting methionine restriction for cancer treatment. Biochem. Pharmacol. 2018, 154, 170-173. [CrossRef] 